\title{
The Backward-Bending Supply Curve in Fisheries-Revisited
}

\author{
Pham Thi Thanh Thuy ${ }^{1,2} \&$ Ola Flaaten ${ }^{1}$ \\ ${ }^{1}$ Norwegian College of Fishery Science, University of Tromsø, Tromsø, Norway \\ ${ }^{2}$ University of Nha Trang, Vietnam \\ Correspondence: Pham Thi Thanh Thuy, Norwegian College of Fishery Science, University of Tromsø, N-9037 \\ Tromsø, Norway. E-mail: thanh.thuy@uit.no
}

Received: February 19, 2013 Accepted: April 17, 2013 Online Published: May 3, 2013

doi:10.5539/jsd.v6n6p15 URL: http://dx.doi.org/10.5539/jsd.v6n6p15

\begin{abstract}
This study discusses and estimates the backward-bending supply curve, using data for three years over a six-year time span from the inshore purse seine fishery in Khanh Hoa province, Vietnam. Four different models are developed for estimation based on fisheries data, in the absence of stock survey data. The estimated maximum sustainable yield for the anchovy in south-central Vietnam ranges from 138 thousand tons to 293 thousand tons. The results reveal that the anchovy stock to some extent is biologically over-exploited, but seems to have rebuilt in recent years. For management it makes sense to use available, cheaply collected fisheries data on harvests, prices and costs, if biological surveys are lacking, which is often the case due to the cost of establishing expensive research capacities and time series.
\end{abstract}

Keywords: backward-bending supply, inshore purse seine fishery, maximum sustainable yield, overfishing, supply function

\section{Introduction}

Overfishing is a huge problem in many developing countries (Pomeroy, 2012; Stobutzki, Silvestre, \& Garces, 2006), resulting in a severe depletion of coastal fish stocks. This problem is also mounting in developed countries (Flaaten, 2013; Organisation for Economic Co-operation and Development [OECD], 2012). To address and solve the problem of overfishing, stock assessment is often considered important from both a biological and a fisheries perspective. However, biological surveys are expensive and take years and may be unrealistic especially for developing countries.

The backward-bending supply curve for open-access fisheries has received little attention in recent years. The original study was introduced by Copes (1970). Clark (1990) refers to a discounted supply curve which is also a backward-bending one, but for the optimal managed fishery. The most recent study on estimation of a supply function, to the best of our knowledge, is that of Nøstbakken and Bjørndal (2003), using data of the North Sea herring fishing industry. They discuss substantial impacts of different regulatory regimes-open-access fishery and optimal managed fishery-on the supply of the North Sea herring fisheries.

The purpose of this paper is to assess fisheries' health in the case of limited information. We show how fisheries data and bioeconomic theory for open-access fisheries can be applied in order to make assessments when no reliable stock assessment data is available. First, we discuss theoretically the backward-bending supply curve. Second, we estimate the supply curve using fisheries data for three years across a six-year time period (2005, 2008,2011 ) of the inshore purse seine fishery in Khanh Hoa province, Vietnam. Third, we identify the biological stock development of the anchovy species, which is a major resource for this fishery. Fourth, the overfishing issue for this inshore purse seine fishery is analysed.

The findings of this study indicate that the harvests are beyond the maximum sustainable yield (MSY). Furthermore, the harvests show a decreasing trend over the six-year period. This suggests that the stock is over-exploited, but on a path to being rebuilt. The short lifespan and high reproduction of the anchovy are probably the reasons behind this development. Hence, to say that the inshore waters in Vietnam are severely depleting is not supported in our findings and should be reconsidered.

The rest of the paper is divided into the following sections. The next section gives a brief description of the overfishing problem and the inshore purse seine fishery in the Khanh Hoa province, Vietnam. This is followed 
by a modelling section on supply functions, developed to estimate the backward-bending supply curve. Then comes a presentation of data and a section on empirical analysis with the estimation models for the backward-bending supply curve for this fishery. In the ensuing two sections, the results are presented and discussed in relation to the problem of overfishing of the actual fishery and in similar fisheries. The conclusion summarises the findings and provides some critical remarks.

\section{The Overfishing Problem and Inshore Purse Seine Fisheries}

\subsection{Overfishing}

A key measure of human well-being often mentioned in fisheries economics is economic rent. Economic rent is generally defined as the difference between revenues and input opportunity costs. Economic rent can be generated both by saving on input costs and by earning additional revenues. Revenue consists of two components: harvest and price. For developing countries, open-access fisheries are normally the cases and for many fishermen, fishing is their only income generating activity. They are therefore motivated to put more efforts into fishing. For instance, when the price is high, the fishermen intensify exploitation. This may lead to greater harvests in the short term, but in the long term, an overexploitation of fish stocks may appear and the harvest will go down as a consequence.

Thus, overfishing and management advices for semi-open-access fisheries have been a great interest for several years. The MSY approach has often been accepted as an objective for fisheries management (Food and Agriculture Organization of the United Nations [FAO], 2009). The concept of MSY is itself based on a model of biological growth. Hence, one can say that MSY means the highest possible annual catch that can be sustained over time, by keeping the stock at the level producing maximum growth. The MSY refers to a hypothetical equilibrium state between the exploited population and the fishing activity. This concept can be used as a reference point to evaluate if a biological resource stock is over- or underexploited or overfishing is existed.

The overfishing problem in waters of less than $50 \mathrm{~m}$ depth in Vietnam is discussed by several authors (Pomeroy, 2010; Thuoc, 2001). There are a number of reasons to believe that some fish stocks are overfished. First, marine harvests have demonstrated a relatively stable increase over the last two decades, from 571 thousand tons in 1985, to 929 thousand tons in 1995 and 1995 thousand tons in 2005 (General Statistic Office of Vietnam [GSO], 2008). Second, the average of 2006-2007 was the same as in 2005 (Flaaten, 2013), whereas the increase from 2000 to 2005 was around 334 thousand tons. Third, the catch per horsepower (HP) decreased from 1.11 tons/HP in 1985 to 0.89 ton/HP in 1991 and to 0.34 ton/HP in 2005. Fourth, landing data and the assessment of marine resources seem to indicate that the harvest in practice has exceeded the MSY since 1986. Other evidence of over-exploitation includes the increased amount of by-catch in trawl fisheries and the smaller sizes of the fish caught (Research Institute for Marine Fisheries [RIMF], 2006).

Nonetheless, the statements on overfishing in Vietnam might be unreliable. The estimation of MSY for the Vietnamese waters varies among researchers and institutions (Chung, Vinh, \& Duc, 2001; Phan \& Luc, 1991; RIMF, 2001; Thi et al., 2007), suggesting a great variance in and low reliability of the estimated harvest. According to RIMF (2001), the MSY for marine fishery resources is 1670 thousand tons, of which the MSY for pelagic fish makes up 694 tons. Chung et al. (2001) maintain that the respective figures are about 2040 thousand tons and 800 thousand tons per year. Their MSY for pelagic fish comprised 690 thousand tons for coastal species and 120 thousand tons for oceanic species.

In Vietnam, almost all fish stock assessments apply the notion of MSY to multi species. The resource estimates in these studies do not take species composition into account. Typically, they rely on biomass estimates and disregard that some species have short lifespans and high reproduction rates, enabling quick stock recovery if fishing pressure ceases. Data on diversity at different biological levels and patterns of resource variability requires expensive and time-consuming surveys, which is unrealistic for developing countries like Vietnam. Further, the statistics in Vietnam are rather weak due to the low categorical resolution and the non-transparent aggregation of data into mere administrative spaces (Zwieten, Densen, \& Thi, 2002). These add to the suspicion about the reliability of the overfishing conclusion in Vietnam.

\subsection{Inshore Purse Seine Fishery}

Inshore purse seine fishery was first introduced by American fishermen in Atlantic Ocean in 1860 and in Pacific Ocean in 1866. The main target of this fishery is pelagic fish. Among these, anchovies normally have the highest yield. Anchovies are small, tiny and silver saltwater fish belonging to Engraulidae (Mediterranean and European) and Anchoa (North America) family. There are about 145 species in 17 genera found in the Indian, Atlantic and Pacific Oceans and Mediterranean Sea. Of those, there are five commercially significant species: Peruvian 
anchovy (Engraulis ringens), European pilchard (Sardina pilchardus), Japanese anchovy (Engraulis japonicus), European anchovy (Engraulis encrasicolus) and Stolephorus anchovy (Fishbase, 2012); and two of five (Stolephorus and Encrasicolus) are found in Vietnam (Phung, 1978; Thi et al., 2007).
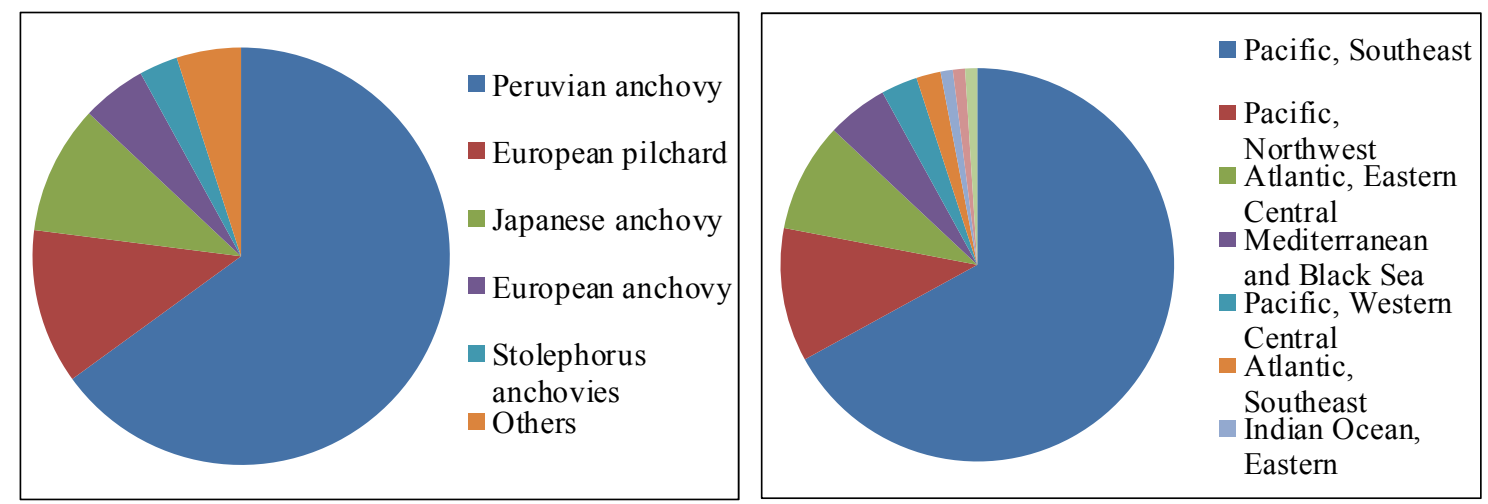

Figure 1. World production of anchovies by species and by fishing area

Source: Eurofish, 2012.

Anchovies are considered one of the most world's traded fish species. In the past years, development of trade of anchovies has been at a high rate, supplying a growing demand for fish products (Eurofish, 2012). The worldwide production of anchovies accounts to nearly 11 million tons in 2009. The major part of the total anchovy production (65 percent) is represented by Peruvian anchovy, with the total production of 7 million tons. The biggest share of the world's production of anchovy by fishing areas thus belongs to the Southeast Pacific Ocean. The second biggest one is came from the Northwest Pacific part which is responsible for 11 percent of the overall anchovy catch, equivalent to a volume of 1 million tons. Such countries as China, Japan, the Republic of Korea, Vietnam and other countries contribute to this anchovy production (see Figure 1).

In Vietnam, the purse seine fishery was initially introduced in the North in 1959 and then in the South in 1975. Nowadays, this fishery is dominant in 29 out of 64 provinces in Vietnam. The purse seine fishery plays an important role in creating economic values and generating jobs for thousands of people. In specific, it contributes to $20.6 \%$ of total catch with the operation of 6,413 fishing vessels.

Purse seining is one of the most widespread inshore fishing industries in the Khanh Hoa province, which is located in south-central Vietnam. Its land area is approximately $5260 \mathrm{~km}^{2}$, with a coastline of more than $520 \mathrm{~km}$. In Khanh Hoa there are about 31500 people working in the fishing sector. They live in fishing villages along the coast. Approximately 30 percent of them are involved in inshore purse seine fisheries (GSO, 2009).

Purse seine fishing implies filtering water to catch fish. The purse seine functions as a wall of net set in the water, surrounding an area, and it is then hauled at either side of the vessel. The target species of purse seiners are mainly anchovy. The average annual operating time is around 8-10 months. The high season starts in February and runs until October. The remaining months are the low season. The fishing ground stretches from Nha Trang to Phan Thiet waters. The purse seiners cannot operate in fishing grounds more than 50 meters deep because of strong water currents and the propulsive forces of the net, which has a very small mesh size $(2 \mathrm{~mm})$.

Until now, there is no study assessing the MSY of the anchovy in south-central Vietnam. Only two studies have evaluated but in other regions: one focused on the coastal waters of Vietnam in general (Phan \& Luc, 1991) and the other on the southeast region (Thi et al., 2007). The authors of the former study estimated the MSY to be 500-600 thousand tons. They did not discuss, though, whether the fishery is under-or overfished. In the latter study, Thi et al. (2007) estimated the MSY to be 72 thousand tons, but the actual harvest was 75 thousand tons. This suggested that there was truly overfishing problem, especially for Shorthead Anchovy (Encrasicholina Heterolobus) and Buccaneer Anchovy (Encrasicholina Punctifer). Both findings were based on Schaefer model (1954) which requires information on fishing effort and harvests and no data on prices and costs of the inshore purse seine fisheries. 


\section{The Backward-Bending Supply Curve for an Open-Access Fishery}

Supply in most sectors increases with an increase in price. However, the supply in an open-access fishery, as pointed out by Copes (1970), is different from those in other sectors. This supply curve may be figured as a backward-bending curve. In the short run, the supply curve in fishery is increasing. But in the long run, it is constrained by the limits to growth of the resource. As fishing efforts are increased, the harvest will eventually start to decline as a consequence of over-exploitation. Even if the price is rising, supply will diminish.

Copes (1970) presents a graphical discussion of the backward-bending supply curve in an open-access fishery but does not give a specific function for estimation. Until now there have been just a few studies developing functions for the backward-bending supply curve in fishery, and they mainly use the Gordon-Schaefer model and its quadratic yield function. This, to some extent, requires biological stock data for the estimation (Berck \& Perloff, 1985; Bjørndal, 1987; Nøstbakken \& Bjørndal, 2003). Our study attempts to estimate the backward-bending supply curve with fisheries data only. Here we develop four different models to examine the validities of the findings.

\subsection{Model 1}

For the sake of mathematical tractability, we assume that long-run open-access supply solely depends on the price, and that harvest technology is given and marginal effort costs are constant. The supply assumption is restrictive since biological and environmental factors could also affect the supply-factors such as natural mortality, weather conditions and seasonal variations. Hence the general form of the supply function may be generalised as:

$$
H=f(p), \quad p>0
$$

where $p$ is the market price and $H$ is harvest.

We specify a long-run supply function:

$$
H(P)=a P e^{-b P} \quad a, b>0
$$

where $e$ is Euler's number, $a$ is a constant harvest per unit price, $b$ relates to the degree of harvest decline when price increases.

We notice that the long-run supply curve in (2) starts at the origin. However, as the fishermen will not go fishing if the price is zero, we must rescale the price, $P$, and let the supply curve start at some point in the price axis, like Copes (1970) argues. Thus, the re-scaled price, $P$, is defined as $P=p-p_{o}$ where $p$ is the market price of raw

fish and $p_{o}$ is the minimum price that induces harvest. The long-run supply function in (2) could be expressed as a function of market price as follows:

$$
H(p)=a\left(p-p_{o}\right) e^{-b\left(p-p_{o}\right)}
$$

\subsection{Model 2 - Based on the Gordon-Schaefer Model}

The Gordon-Schaefer model (Clark, 1990) is the combined catch equilibrium model based on logistic growth and harvest per unit of effort proportional to stock size. The backward-bending supply curve for this model will now be derived. On the basis of the logistic growth model_and simplifying economic assumptions, they propose stock change per unit of time as:

$$
d X / d t=G(X)-H,
$$

where $X$ is the stock size. The logistic growth model, $G(X)$, is specified as:

$$
G(X)=r X(1-X / K),
$$

where $\mathrm{r}$ is the intrinsic growth rate and $K$ is the carrying capacity.

Therefore (4) can be rewritten:

$$
d X / d t=r X(1-X / K)-H .
$$

At equilibrium, $d X / d t=0$, the stock $X$ remains constant and the sustainable yield equals biological growth, $H=G(X)$ (Clark, 1990; Flaaten, 2011; Schaefer, 1954). Hence (6) may be expressed as:

$$
H=r X(1-X / K) \text {. }
$$

The harvest is given by the following Schaefer function:

$$
H=q E X,
$$

with its linear relationship between the two inputs, fishing effort $E$ and stock biomass $X$. The coefficient $q$ is referred to as the catchability. The Schaefer harvest function implies that the harvest will increase at the same 
rate with the increase of the stock, if the effort is fixed. In empirical work the number of vessels or fishing days is often used as proxies of fishing effort, $E$. In this study the former is used.

Assuming that the market price of raw fish, $p$, is constant, this implies that total revenue is:

$$
T R(E)=p H=p q E X .
$$

Assuming that the cost per vessel per year is constant, $c$, the total cost of the fishery is:

$$
T C(E)=c E \text {. }
$$

At the bioeconomic equilibrium under open-access, the average revenue of effort equals the marginal cost of effort, $A R(E)=M C(E)$, which implies the equilibrium stock $X^{\infty}=c / p q$. We notice that $p>c / q K$ because $X^{\infty}<K$. If the market price, $p$, is equal to or less than $c / q K$, the harvest, $H$, equals zero with no vessels participating in the fishery. In other words, the minimum price is $p_{o}=c / q K$. Also note that the definition of the maximum equilibrium stock level without fishing, $K$, may vary from model to model. If we express a correlation between the equilibrium stock, $X^{\infty}$, and the prices $p$ and $p_{o}$, then:

$$
X^{\infty}=K p_{o} / p
$$

Substituting $X^{\infty}$ from (11) for $X$ into (7) gives the open-access long-run backward-bending supply curve:

\subsection{Model 3 - Based on the Ricker Model}

$$
H(p)=r K p_{o} / p\left(1-p_{o} / p\right)
$$

The Ricker model (Ricker, 1954) is a classic discrete population model which gives the expected biomass $X_{t+1}$ in generation $t+1$ as a function of the biomass in the previous generation:

$$
X_{t+1}=X_{t} e^{r\left(1-X_{t} / K\right)}
$$

From (13), we model the natural growth function:

$$
d X / d t=F(X)=X e^{r(1-X / K)}-X
$$

Substituting $X^{\infty}$ from (11) for $X$ into (14), we obtain the following backward-bending supply curve in the open-access fisheries:

$$
H(p)=K p_{o} / p e^{r\left(1-p_{o} / p\right)}-K p_{o} / p
$$

\subsection{Model 4 - Based on the Gompertz-Fox Model}

In the Gompertz-Fox model (Fox, 1970), it is assumed that the biological growth follows the Gompertz growth function:

$$
G(X)=-r X \ln (X / K)
$$

Hence, to derive the supply curve as a function of the market price, p, substitute $X^{\infty}$ from (11) for X into (16):

$$
H(p)=-r K p_{o} / p \ln \left(p_{o} / p\right)
$$

Note that the interpretations of the growth parameters, $r$, are somewhat different among the models, whereas the carrying capacity, $K$, has the same meaning in the models.

The general nature of the four models is that the harvest increases with price until price reaches the level that produces MSY. Then it falls, bends backward, and approaches zero as price goes to infinity. Thus all the models are hump-shaped curves in price, exhibiting a decline in harvest at a higher price (Figure 2). 


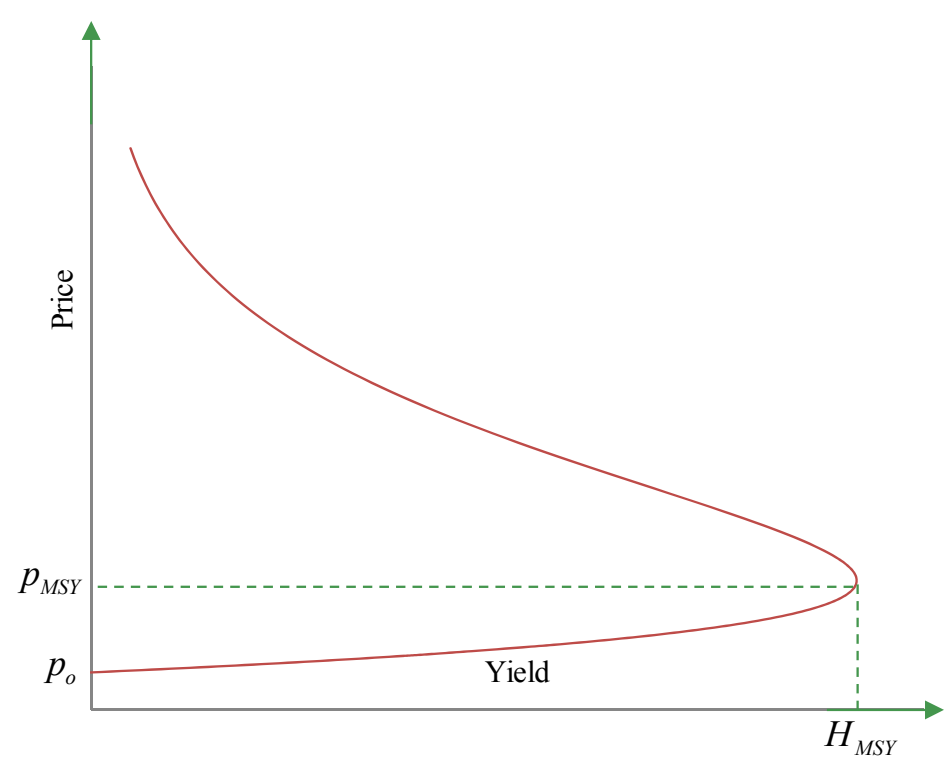

Figure 2. The backward-bending supply curve in open-access fisheries

Table 1 shows the characteristics of the models: the backward-bending harvest functions and price and yield that correspond to the MSY level. These figures are derived by taking the derivatives of the harvest with respect to price in the four supply functions. However, in model 3, we cannot determine explicitly $p_{M S Y}$ by analytical analysis but use numerical scheme such as Newton's method to estimate (see Appendix A).

Table 1. The backward-bending harvest functions and prices and yields at the MSY levels

\begin{tabular}{cccc}
\hline \multirow{2}{*}{ Model } & $\begin{array}{c}\text { Backward-bending } \\
\text { harvest function }\end{array}$ & Price & MSY \\
\cline { 3 - 4 } & $H(p)=a\left(p-p_{o}\right) e^{-b\left(p-p_{o}\right)}$ & $p_{M S Y}=1 / b+p_{o}$ & $H_{M S Y}=a / b e$ \\
\hline Model 1 & $H(p)=r K p_{o} / p\left(1-p_{o} / p\right)$ & $p_{M S Y}=2 p_{o}$ & $H_{M S Y}=r K / 4$ \\
Model 2 & $H(p)=K p_{o} / p e^{r\left(1-p_{o} / p\right)}-K p_{o} / p$ & $e^{r\left(1-p_{o} / p_{M S Y}\right)}\left(1-r p_{o} / p_{M S Y}\right)-1=0$ & $H_{M S Y}=K p_{o} / p\left(1 /\left(1-r p_{o} / p\right)-1\right)$ \\
Model 3 & $H(p)=-r K p_{o} / p \ln \left(p_{o} / p\right)$ & $p_{M S Y}=e p_{o}$ & $H_{M S Y}=r K / e$ \\
Model 4 & $H(p)$ &
\end{tabular}

\section{Data}

The data for this study is of 169 fishing households involved in the purse seine fishery in the Khanh Hoa province, Vietnam. Data were collected for three years: 57 forms for 2005, 50 forms for 2008 and 62 for 2011. We employed the stratified sampling method and used a questionnaire to interview directly the vessel owners (see Appendix B). The representatives of the samples are tested in Table 2.

Table 2. Sample Representative Test: using Hull Length (m) as the Measure

\begin{tabular}{|c|c|c|c|c|c|c|}
\hline \multirow{2}{*}{ Year } & \multicolumn{3}{|c|}{ Sample } & \multirow{2}{*}{$\begin{array}{c}\text { Mean of } \\
\text { the population }\end{array}$} & \multirow{2}{*}{$\begin{array}{c}\text { t-test } \\
\text { statistics }\end{array}$} & \multirow{2}{*}{$\mathrm{p}$-value } \\
\hline & Observation & Mean & Standard deviation & & & \\
\hline 2005 & 57 & 12.53 & 2.14 & 13.31 & -3.56 & 0.00 \\
\hline 2008 & 50 & 11.85 & 2.38 & 12.55 & -2.03 & 0.03 \\
\hline 2011 & 62 & 14.29 & 1.15 & 14.07 & 1.75 & 0.08 \\
\hline
\end{tabular}

Source: Own calculations; ${ }^{b}$ Department of Capture Fisheries and Resources Protection of Khanh Hoa [Khanh Hoa's DECAFIREP], 2006, 2009, 2012. 
In order to estimate the backward-bending supply curve, the following data is needed: total cost, harvest and price. Total cost includes the operating cost, labor cost and depreciation cost. The average cost per vessel over the period, $c$, is computed by the sum of total cost of all vessels participating in the fishery divided by the number of these vessels in these three years $\left(c=\sum T C_{i t} / \sum E_{t}\right)$. The number of vessels involving in the fishery is reported by the department of capture fisheries and resources protection of Khanh Hoa. The harvest is the annual average harvest of the total vessels practicing in the inshore purse seine fishery. The price used is the price received by individual vessel. The prices and costs in 2005 and 2008 are inflated to 2011 by the consumer price index to rid of economic causes affecting prices (Note 1). The key information of the data is shown in Table 3.

Table 3. Characteristics of the inshore purse seine fishery: mean with standard error in parenthesis

\begin{tabular}{lcccc}
\hline \multirow{2}{*}{ Criteria } & \multirow{2}{*}{ Unit } & \multicolumn{3}{c}{ Year } \\
\cline { 3 - 5 } & & 2005 & 2008 & 2011 \\
\hline Per vessel & & & & \\
Number of observations & vessel & 57 & 50 & 62 \\
& & 877 & 1447 & 1334 \\
Total cost (1) & million VND & $(41.62)$ & $(49.01)$ & $(43.44)$ \\
& & 80 & 87 & 230 \\
Harvest (2) & ton & $(3.71)$ & $(2.87)$ & $(15.34)$ \\
Population & & & & \\
Number of vessels (3) & vessel & 867 & 1153 & 581 \\
Engine & HP & 27.00 & 22.00 & 37.50 \\
Total harvest $(4=3 \times 2)$ & ton & 69360 & 100311 & 133630 \\
\hline
\end{tabular}

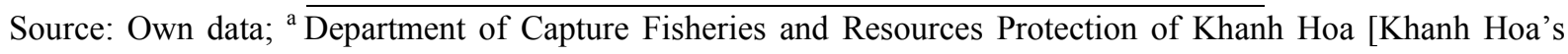
DECAFIREP], 2006, 2009, 2012.

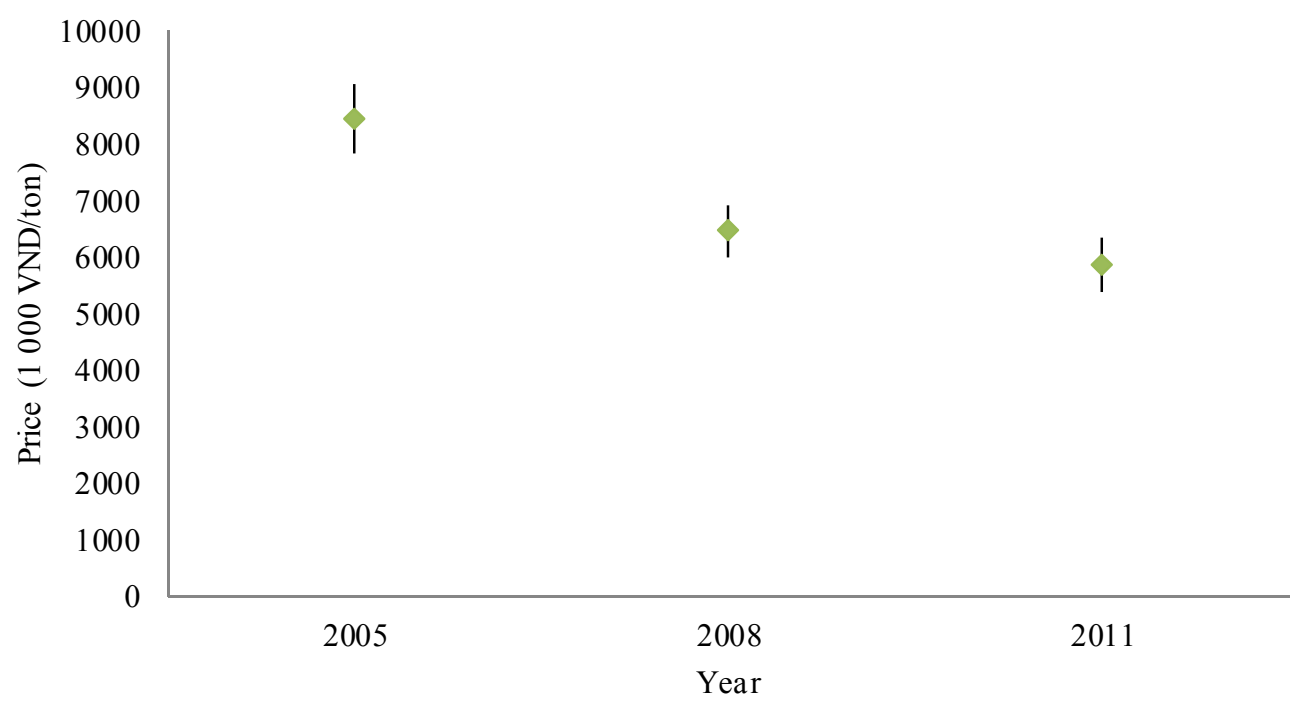

Figure 3. Market prices. Plots of the market price fluctuation of the fishery grouped in the years of 2005, 2008 and 2011. Average price of each year and the corresponding standard deviation are indicated as dot and solid vertical line, respectively

In Vietnam, anchovy products come to consumers by many different ways including retailers, supermarkets, schools, restaurants etc... - often after a number of intermediaries. Typically, all the harvest is sold to middlemen before going to other traders and consumers. Fishermen tend to accept the prices from middlemen. The main 
reasons are that the fishermen offer a perishable good, have few alternative outlets, and normally have limited information about prices. We observed that prices varied among vessels and over years. A graphical presentation of the market price variation is presented in Figure 3.

Table 3 shows a substantial increase in harvest, while Figure 3 indicates a decreasing trend in price from 2005 to 2011. The figures may imply a rebuilding trend of anchovy stock during the period. We examine this prediction in the following sections.

\section{Empirical Analysis}

\subsection{Model 1}

For computational purposes, Equation (3) may be expressed in log-form:

$$
\ln H_{j t}=\ln a+\ln \left(p_{j t}-p_{o}\right)-b\left(p_{j t}-p_{o}\right)=\alpha+\ln \left(p_{j t}-p_{o}\right)+\beta\left(p_{j t}-p_{o}\right)
$$

where $\alpha=\ln a$ and $\beta=-b ; t$ indicates year $(t=2005,2008$ and 2011) and $j$ indicates different price observation.

Before analysing equation (18), it is necessary to determine the minimum price that induces harvest for the industry. This is indeed the average cost per unit of harvest of the most cost efficient vessel operating. The most cost efficient vessel is selected by identifying the lowest average cost per unit of harvest among the vessels during the period 2005-2011. This is summarised as:

$$
p_{o}=\min A C_{i t}=\operatorname{minTC} C_{i t} / H_{i t},
$$

where $T C_{i t}$ and $H_{i t}$ are the total cost and the harvest of the $i^{\prime}$ th vessel in year $t$, respectively;

\subsection{Model 2 - Based on the Gordon-Schaefer Model}

Equation (12) is rewritten as:

where $\alpha=r K p_{o}$ and $\beta=-r K p_{o}{ }^{2}$

$$
H_{j t}=r K p_{o} 1 / p_{j t}-r K p_{o}^{2}\left(1 / p_{j t}\right)^{2}=\alpha 1 / p_{j t}+\beta\left(1 / p_{j t}\right)^{2},
$$

\subsection{Model 3 - Based on the Ricker Model}

Equation (15) may be expressed in a following form:

where $\alpha=K e^{r} p_{o}, \beta=-r p_{o}$, and $\gamma=-p_{o} K$

$$
H_{j t}=K e^{r} p_{o} 1 / p_{j t} e^{-r p_{o} 1 / p_{j t}}-p_{o} K 1 / p_{j t}=\alpha 1 / p_{j t} e^{\beta 1 / p_{j t}}+\gamma 1 / p_{j t}
$$

\subsection{Model 4 - Based on the Gompertz-Fox Model}

We can rewrite equation (17) as follows:

$$
\begin{aligned}
& H_{j t}=r K p_{o} 1 / p_{j t}\left(\ln p_{o}+\ln 1 / p_{j t}\right)=-r K p_{o} 1 / p_{j t} \ln 1 / p_{j t}-r K p_{o} \ln p_{o} 1 / p_{j t} \\
& =\alpha 1 / p_{j t} \ln 1 / p_{j t}+\beta 1 / p_{j t}
\end{aligned}
$$

where $\alpha=-r K p_{o}$ and $\beta=-r K p_{o} \ln p_{o}$

In order to estimate the backward-bending supply curve for the inshore purse seine fishery, we apply weighted linear least square estimate for model 1,2, 4 and weighted nonlinear least square estimate for model 3 . Weights are measured by frequencies of the observed prices. In particular, observed prices with large frequencies shall influence the estimated supply curve more than prices with smaller frequencies. To satisfy the functional form of the backward-bending curve, additional conditions are applied: estimated coefficient for $\ln \left(p_{j t}-p_{o}\right)$ is constrained to be one in model 1; model 2 and 4 are constrained to regress with zero intercept. The regression with zero intercept has been arguing to remain controversy and confusion. But in some cases, it is unavoidable due to transformation of models. Therefore, this regression is acceptable (Eisenhauer, 2003).

\section{Results}

The estimated results of the models are presented in Table 4. 
Table 4. Estimates of the backward-bending supply curves for the inshore purse seine fishery (standard error in parenthesis)

\begin{tabular}{lcccc}
\hline Coefficients & Model 1 & Model 2 & Model 3 & Model 4 \\
\hline$\alpha$ & $\ln a=12^{*}$ & $r K p_{o}=944813^{*}$ & $K e^{r} p_{o}=8341459^{*}$ & $-r K p_{o}=-222027^{*}$ \\
& $(0.06)$ & $(56131)$ & $(58250)$ & $(61656)$ \\
$\beta$ & $-b=-0.42^{*}(0.01)$ & $-r K p_{o}{ }^{2}=-1567302^{*}$ & $-r p_{o}=-0.19^{*}$ & $-r K p_{o} \ln p_{o}=283480^{* *}(116919)$ \\
$\gamma$ & $(354556)$ & $(0.04)$ & \\
Adjusted $R^{2}$ & 0.53 & & $-p_{o} K=-7394166^{*}$ & \\
Observation & 169 & 0.95 & $(40785)$ & 0.95 \\
\hline *** : significant at $1 \%$ and 5\% level & 169 & 169 &
\end{tabular}

The estimated coefficients for each model are shown in Table 4. The coefficients are significant, ranging from $95 \%$ to $99 \%$ levels for all models. The standard errors are small. The test statistics adjusted $R^{2}$ explain from $53 \%$ to $95 \%$ of the observed variation, indicating that the models give reasonable fit to the data.

The specific supply functions, the prices that produce MSY levels and the corresponding harvests of the four models are presented in Table 5. In model 1, the estimated supply curve starts to bend backward as a consequence of biological overfishing at a price of 5160 thousand VND per ton (corresponding to 248 USD per ton) with the corresponding harvest of 143 thousand tons, while the curve designated by model 2 bends at a lower price of 3318 thousand VND per ton (corresponding to 159 USD per ton) and lower harvest of 142 thousand tons. The results in model 3 are relatively close to those in model 1 with a price of 3360 thousand VND per ton (corresponding to 161 USD per ton) and a harvest of 138 thousand tons. Model 4 has the highest sustainable yield (293 thousand tons) which is about twofold higher than those of the other three models.

Table5. The predicted backward-bending harvest functions and prices and yields at the MSY level of the four models

\begin{tabular}{|c|c|c|c|}
\hline \multirow[b]{2}{*}{ Model } & \multirow[b]{2}{*}{$\begin{array}{l}\text { Backward-bending } \\
\text { harvest function }\end{array}$} & \multicolumn{2}{|c|}{ MSY } \\
\hline & & $\begin{array}{c}\text { Price } \\
(1000 \mathrm{VND} / \text { ton })\end{array}$ & $\begin{array}{c}\text { Yield } \\
\text { ( thousand ton) }\end{array}$ \\
\hline Model 1 & $H(P)=162755(p-2.78) e^{-0.42(p-2.78)}$ & 5160 & 143 \\
\hline Model 2 & $H(p)=944813 / p(1-1.66 / p)$ & 3318 & 142 \\
\hline Model 3 & $H(p)=7394166 / p e^{0.12(1-1.66 / p)}-7394166 / p$ & 3360 & 138 \\
\hline Model 4 & $H(p)=-222027 / p \ln (0.28 / p)$ & 760 & 293 \\
\hline
\end{tabular}

The backward-bending supply curves for the purse seine fishery designated by model 1 to model 4 are shown in Figure 3. The curves are relatively similar in shape and direction. All curves are upward sloping over the price. The curves start backward-bending as a consequence of biological overfishing when the prices exceed the levels that produce MSY. The mechanisms behind these curves are that, as price goes up, the fishermen increase their fishing effort. Harvest increases with the increase in effort until it reaches the MSY level. Further increases in effort will reduce the sustainable harvest due to biological overfishing. Fishermen expand effort to the equilibrium point where average revenue of effort equals marginal cost of effort, due to the reduced stock and increased unit harvest costs.

The estimated minimum price varies among the four models, ranging from 300 to 2780 thousand VND per ton (corresponding to 14 to 133 USD per ton). This implies that the fishermen will stop fishing at these minimum prices because they do not get any economic rent, but they might go fishing if the market price exceeds the minimum price. With regards to model 1, the harvest supplied is approaching zero if the price is equal to or less 
than 2780 thousand VND per ton (corresponding to 133 USD per ton). In model 2 and 3, the minimum prices are both equal to 1660 thousand VND per ton (corresponding to 80 USD per ton). However, this figure is pretty much lower in model 4, only 300 thousand VND per ton (corresponding to 14 USD per ton). In short, estimated minimum prices in model 2, 3 and 4 are derived from the empirical models. As mentioned above, these models are formulated based on the linear cost function which means the vessels are homogeneous in terms of capital and labor. In contrast, model 1 is built up without the assumption of a linear cost function; the minimum price is measured by selecting the minimum unit cost of harvest among the heterogeneous vessels. The fact that vessels are different is always the case in reality. Thus, the estimated minimum price in model 1 seems realistic and is preferred in this study.

The results of model 4 are relatively different from those of the other three models. We argue three reasons for this. First, the functional natures of the models are different. Second, the growth parameter, $r$, has somewhat different meanings among the models. Third, transformation of the models to apply econometrics might lead to errors in the results. For instance, it is clear that model 4 is transformed while model 2 is kept to the original form before we apply empirical analysis.

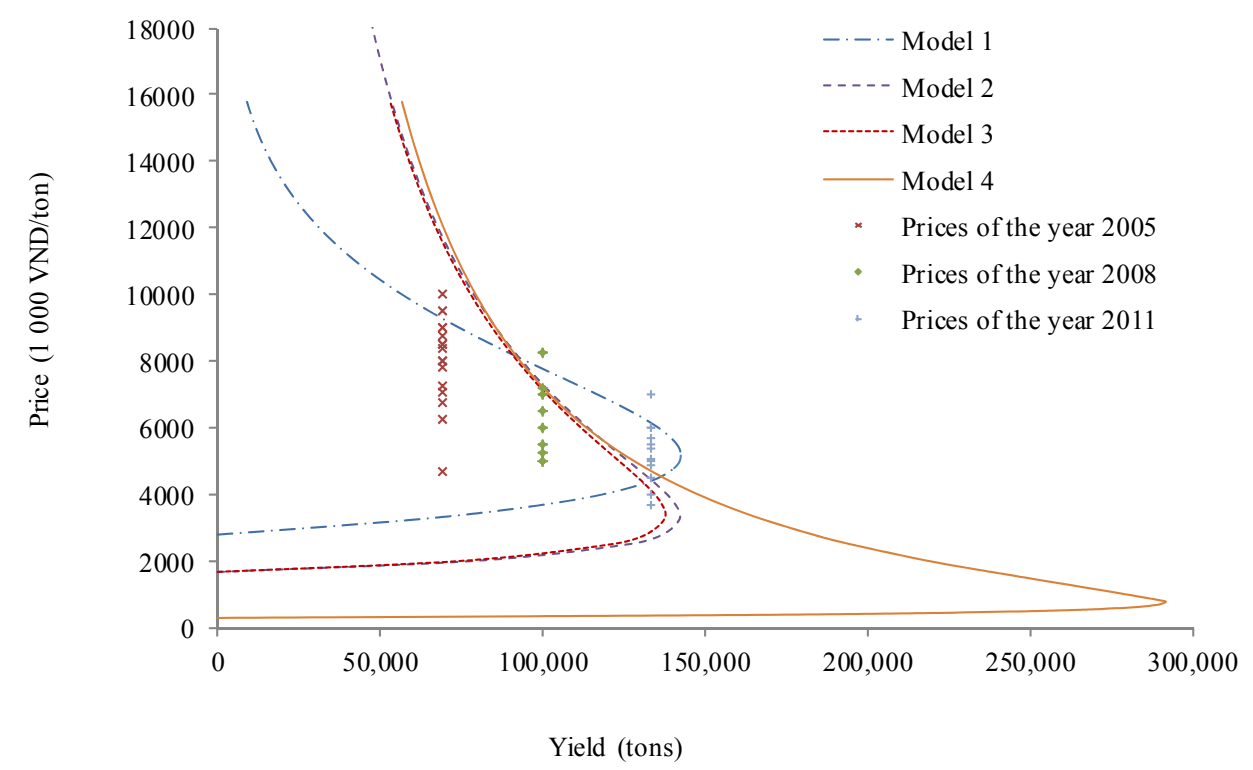

Figure 4. Estimated backward-bending supply curves for the inshore purse seine fishery

Interestingly, the biological parameters can be derived in model 3. Particularly, $r$ is 0.12 per year, $K$ is 4456716 tons and $X_{M S Y}$ is 2200000 tons. The estimated intrinsic growth rate for the population is lower than those for individual anchovy species reported by Thi et al. (2007). With regard to $K$ and $X_{M S Y}$, to the best of our knowledge, no study has reported them previously. Thus, this indicates a need for further research into these parameters.

\section{Discussion}

The theoretical models discussed above are at the centre of bioeconomic theory. Among these, the Gordon-Schaefer static model is considered as a pioneer one of a single species commercial fisheries analysis. It illustrates the economic inefficiency of an open-access fishery compared with the economically optimal efficiency. Even though these models have a drawback for dynamic fisheries, they are still worthy in fisheries management, at least as a first step. A notable feature is that both the different dynamic models and the basic Gordon-Schaefer model have the similar broad conclusions (Clark, 2006). This feature perhaps makes dynamic models seem unnecessary or too complex to be implemented in fisheries management in developing countries, and it may explain why single species models are often favored for understanding problems that do not take into account spatial heterogeneity or ecosystems (Larkin at al., 2011). 
The estimated MSY of the south-central region is around two to three times higher than that of the southwest area reported by Thi et al. (2007). This high yield of anchovy is proved in south-central Vietnam (Phan \& Luc, 1991).

The study provides some interesting results. It is clear that biological overfishing has taken place in south-central Vietnam. As shown in the price-yield graphs of Figure 4, the harvests of the three years in question are beyond the estimated MSYs of the four models. Nevertheless, the results clearly demonstrate that the price has been falling and the annual harvest has been increasing over the period 2005-2011. This might indicate that a rebuilding of the anchovy stock in south-central Vietnam is actually taking place.

The biological characteristics of the anchovy species lend good support to the findings and arguments in this paper. Regarding intrinsic growth, anchovies have relatively high rates, ranging from 0.53 to 0.90 per year, in which Shorthead species is reported as the highest level (Thi et al., 2007). A great ratio of this species was found in this survey. In general, lifespan and reproduction of anchovies are short. The details of their lifespan and reproduction are presented in Table 6 (Note 2).

Table 6. The lifespan and reproduction of anchovy

Unit: year

\begin{tabular}{|c|c|c|c|c|}
\hline \multirow[b]{2}{*}{ Species } & \multicolumn{3}{|c|}{ Age $_{\text {max }}$} & \multirow{2}{*}{$\begin{array}{l}\text { Reproduction } \\
\text { (Fishbase) }\end{array}$} \\
\hline & $\begin{array}{c}\text { (Phan \& Luc, } \\
\text { 1991) }\end{array}$ & $\begin{array}{l}\text { (Thi et al., } \\
\text { 2007) }\end{array}$ & (Fishbase) & \\
\hline $\begin{array}{c}\text { Devis' Anchovy (Encrasicholina } \\
\text { Devisi) }\end{array}$ & & 3.9 & 1.2 & 0.5 \\
\hline $\begin{array}{c}\text { Shorthead Anchovy (Encrasicholina } \\
\text { Heterolobus) }\end{array}$ & & 3.3 & 1.2 & 0.5 \\
\hline $\begin{array}{c}\text { Buccaneer Anchovy } \\
\text { (Encrasicholina Punctifer) }\end{array}$ & 3.0 & 4.0 & 2.3 & 0.9 \\
\hline $\begin{array}{l}\text { Commerson's Anchovy } \\
\text { (Stolephorus Commersonnii) }\end{array}$ & & 3.5 & 2.2 & 0.9 \\
\hline $\begin{array}{c}\text { Indian Anchovy } \\
\text { (Stolephorus Indicus) }\end{array}$ & & 5.0 & 2.7 & 1.0 \\
\hline
\end{tabular}

In order to rebuild a fish stock, the fishing effort involved in the fishery has to be reduced (Flaaten, 2011). However, the number of vessels presented in Table 3 has not been decreasing over time, as predicted by the open-access analysis. There could be a couple of reasons for this. First, data of vessels may be incorrect due to misreporting, registration mistakes, and so on. The total number of vessels in 2008 might have been overestimated due to the ad hoc subsidy policy for that particular year. Partial compensation was offered to all vessels to mitigate the costs from the increase in fuel prices, resulting in the registration of many previously unregistered vessels. This argument is supported by the fact that the average horsepower of the vessels was smaller in 2008 compared to 2005 (see Table 3). The registration of vessels with less than $20 \mathrm{HP}$ led to a lower average horsepower than in the previous years. Second, in contrast to 2008, the number of vessels in 2011 might have been underestimated. This is because the government in general does not take responsibility for monitoring and controlling vessels with engines less than 20HP. From 2011 local authorities were obliged to register all such vessels, but data was unavailable at the time of the survey for this study (Note 3).

The harvest and price data have been treated as exact figures, even though they may include measurement errors. Normally, price data with an error term are preferred in studies of tropical fisheries. The reliability of the harvest data depends to a great extent on the answers of fishermen who have a limited educational background and very simple bookkeeping systems. Different prices are normally observed for different fish species and fishing trips. However, the average prices are often given when the fishermen are asked in interviews. Nevertheless, when comparing data collected in this and related studies of the Khanh Hoa fisheries, the overall picture fits well with the bioeconomic theory of open-access fisheries (see e.g. Duy, Flaaten, Kim Anh, \& Ngoc, 2012; Thuy, Flaaten \& Kim Anh, in press). 
The fishing effort of the fishery over the period of six years in this study is measured by the number of vessels operating. This does not take into account differences in technical characteristics such as gears, engines and hull length, and such characteristics may change over years due to modernisation and investments. For example, Table 3 shows that the average horsepower of the fishery varies over the period. As discussed above, the number of vessels in the population in 2008 is greater than in 2005 and 2011, but with a smaller average horsepower. To deal with this problem, we would need detailed data such as horse power, gear and fishing days of all the vessels operating as well as an advanced method to standardize effort. The issue of standardizing fishing effort under the assumption of constant stock has been discussed in the literature (Duy et al., 2012) but have not received much scholarly attention when the stock is variable. Hence, the study leaves this question for future research. This research is based on fisheries data in terms of prices, costs and catches, and it demonstrates that, even if we do not have biological assessment data, the health situation of the fishery could be evaluated. For the management bodies such knowledge may be useful in relation to the overfishing issue, in particular since biological surveys are not available and would be costly and take years to acquire.

Considering the graphs of the four estimated backward-bending supply curves in Figure 4, it looks like a further reduction in the fish price will realise catches closer to the maximum sustainable yield. What could be done to promote harvests in accordance with MSY? When it comes to policy instruments it is pertinent in this context to discuss briefly a tax per unit of catch since it is the ex-vessel price of fish which is the driving force in the backward bending yield curve analysis. It has been demonstrated in the bioeconomic literature for the Gordon-Schaefer type of models that biological, and economical overfishing could be solved by introducing a tax on harvest or effort, as well as a transferable quota or effort licencing system (Clark, 1980). However, in actual fisheries resources and fishing fleets are often more complex than in the models, and any policy instrument should be carefully considered. Fishermen stay in the fishery for profit and earnings in relation to their opportunity costs, which may include different types of social costs and their individual valuation of leisure time, and they go fishing as long as this difference is positive. A tax per unit of catch would reduce the incentive for fishing. Of course there may be dissimilarities between the short and the long run. For the former it is sufficient that vessels cover their operational costs, whereas the backward-bending curves are based on full cost coverage and equilibrium for each price level displayed in Figure 4. If the overall objective of the fisheries' policy is welfare maximisation, including not just resource rent, but also consumer surplus and producer surplus (intra-marginal rent), the optimal sustainable yield may in some cases be close to the MSY (Béné, Hersoug, \& Allison, 2010; Copes, 1972).

With many vessels and landing places, as well as weak management for monitoring, control and enforcement, implementation of a landing tax may be difficult from an efficiency point of view. In addition, it may be socially difficult to make a tax work effectively by reducing profit and earnings to such low levels that some vessels and crew are forced out of the fishery. An alternative to landing tax is an export tax where the fewer export points and the existence of trade institutions can make this de facto resource tax work more efficiently than at the ex-vessel level (Flaaten \& Schulz, 2010). The export tax will in the competitive export markets, via processing companies and middlemen, spill over to the ex-vessel fish market, thus functioning indirectly as a landing tax for the exported fish. Any policy instrument working to reduce the effort or limit the total catch in a fishery implies that some vessels and fishermen have to leave the fishery. Therefore the livelihood alternatives will be of importance for the success of the fisheries' policy (Béné et al., 2010). If such adequate alternatives do not exist, the policy will inevitably fail, forcing fishermen back to the open- or semi-open fisheries, and creating enforcement problems in the managed parts of the industry.

Globally, many regulatory tools are applied in fisheries such as quotas, vessel licensing, minimum mesh size restriction, seasonal and area closure, but the compliance with these regulations is questionable. In the case of mainly small-scale Vietnamese fisheries, even getting vessels to register has proved difficult for the smaller ones (Khanh Hoa's DECAFIREP, 2012). To change the purse seine fishery analysed from open access to welfare maximisation requires designing a policy plan that can work under the current and future resource, economic and institutional frameworks. However, the details of this are considered outside the scope of this paper.

\section{Conclusion}

This study has discussed theoretically and empirically the backward-bending supply curve, which has until now received little attention in the economic literature. The aggregate fisheries data of an open access inshore purse seine fishery has been used for the analysis. The MSY for the anchovy stock in south-central Vietnam has been estimated, ranging from 138 thousand to 293 thousand tons, with the corresponding market price varying from 760 to 5160 thousand VND per ton, corresponding to 36 to 248 USD per ton. It was found that the fishermen will stop fishing if the price per ton is equal to or lower than 2780 thousand VND, corresponding to 130 USD 
per ton, for which the most cost efficient vessel will barely break even in the long run when both operating and fixed costs should be covered.

The four models estimated indicate that the inshore fishery is a bit more than fully exploited in terms of maximising sustainable yield. However, the harvest has been increasing over the investigated years and is becoming rather close to the MSY. Thus the biological overfishing problem does not seem severe in the case of anchovy fisheries in south-central Vietnam. This argument is further supported by the fact that anchovy has a short lifespan, rapid intrinsic growth rates and high reproduction, making it able to recover in a rather short time. Hence, when assessing the overfishing problem, the biological characteristics of the investigated species as well as fishing waters should be considered.

For management it may make sense to use available, cheaply collected fisheries data on harvests, prices and costs, if more comprehensive biological surveys are lacking. This study reveals that the biological tendency of the stock could be evaluated by looking at the economic side only. If management of fisheries in developing countries should wait for biological surveys, which are normally expensive and time consuming, they may wait in vain. Uncertainties in fisheries inherently exist for biological, economic and social processes and data, and to reduce such weaknesses along the developing path will prove beneficial. But it will also incur costs. Data collection and analyses do not come for free. For this reason, existing or cheaply collected data should be used carefully in combination with theories for fishermen's and firms' behaviour under open access or other actual institutional arrangements.

\section{References}

Béné, C., Hersoug, B., \& Allison, E. H. (2010). Not by rent alone: Analysing the pro-poor functions of small-scale fisheries in developing countries. Development Policy Review, 28, 325-358. http://dx.doi.org/10.1111/j.1467-7679.2010.00486.x

Berck, P., \& Perloff, J. M. (1985). The commons as a natural barrier: Why there are so few fish farms. American Journal of Agricultural Economics, 67(2), 360-363. http://dx.doi.org/10.2307/1240698

Bjørndal, T. (1987). Production economics and optimal stock size in a north Atlantic fishery. The Scandinavian Journal of Economics, 89(2), 145-164. http://dx.doi.org/10.2307/3440061

Chung, B. D., Vinh, C. T., \& Duc, N. H. (2001). Marine fisheries resources-basic development of marine fisheries industry in Vietnam. In Proceedings of Marine Fisheries Research (Vol. II, pp. 200-210). Hai Phong, Vietnam: Research Institute of Marine Fisheries.

Clark, C. W. (1980). Towards a predictive model for the economic regulation of commercial fisheries. Canadian Journal of Fisheries and Aquatic Sciences, 37(7), 1111-1129. http://dx.doi.org/10.1139/f80-144

Clark, C. W. (1990). Mathematical bioeconomics - The optimal management of renewable resources. New York, NY: Wiley \& Sons.

Clark, C. W. (2006). Fisheries bioeconomics: Why is it so widely misunderstood? Population Ecology, 48(2), 95-98. http://dx.doi.org/10.1007/s10144-006-0255-2

Copes, P. (1970). The backward-bending supply curve of the fishing industry. Scottish Journal of Political Economy, 17, 69-77.

Copes, P. (1972). Factor rents, sole ownership and the optimum level of fisheries exploitation. The Manchester School of Social and Economic Studies, 40, 145-163. http://dx.doi.org/10.1111/j.1467-9957.1972.tb01106.x

Department of Capture Fisheries and Resources Protection of Khanh Hoa (Khanh Hoa's DECAFIREP). (2006). The annual report of the number of vessels and engine power registered in 2005 (In Vietnamese). Khanh Hoa, Vietnam.

Department of Capture Fisheries and Resources Protection of Khanh Hoa (Khanh Hoa's DECAFIREP). (2009). The annual report of the number of vessels and engine power registered in 2008 (In Vietnamese). Khanh Hoa, Vietnam.

Department of Capture Fisheries and Resources Protection of Khanh Hoa (Khanh Hoa's DECAFIREP). (2012). The annual report of the number of vessels and engine power registered in 2011 (In Vietnamese). Khanh Hoa, Vietnam.

Duy, N. N., Flaaten, O., Kim Anh, T. N., \& Ngoc, K. T. Q. (2012). Open-access fishing rent and efficiency - the case of gillnet vessels in Nha Trang, Vietnam. Fisheries Research, 127-128, 98-108. http://dx.doi.org/10.1016/j.fishres.2012.04.008 
Eisenhauer, J. G. (2003). Regression through the origin. Teaching Statistics, 25(3). http://dx.doi.org/10.1111/1467-9639.00136

Eurofish international organization. (2012). Overview of the world's anchpvy sector and trade possibilities for Georgian anchovy products. Retrieved from http://www.fao.org/fileadmin/user_upload/Europe/documents/Publications/Anchovies_report_2.03.2012.pd $\mathrm{f}$

Fishbase. (2012). Search for lifespan and generation time of anchovy. Retrieved November 20, 2012, from http://www.fishbase.org/search.php

Flaaten, O. (2011). Fisheries economics and management. Tromsø, Norway: The Norwegian College of Fishery Science, University of Tromsø. Retrieved from http://www.maremacentre.com/bioeconomics

Flaaten, O. (2013). Institutional quality and catch performance of fishing nations. Marine Policy, 38, $267-276$. http://dx.doi.org/10.1016/j.marpol.2012.06.002

Flaaten, O., \& Schulz, C. E. (2010). Triple win for trade in renewable resource goods by use of export taxes. Ecological Economics, 69, 1076-1082. http://dx.doi.org/10.1016/j.ecolecon.2009.11.029

Food and Agriculture Organisation of the United Nations (FAO). (1995). Code of conduct for responsible fisheries. Rome: Italy. Retrived from ftp://ftp.fao.org/docrep/fao/005/v9878e/v9878e00.pdf

Fox, W. W. (1970). An exponential surplus-yield model for optimizing exploited fish populations. Transaction of $\begin{array}{llll}\text { the American } \quad \text { Fisheries } & \text { Society, } & 99(1), & 80-83 .\end{array}$ http://dx.doi.org/10.1577/1548-8659(1970)99<80:AESMFO>2.0.CO;2

General Statistic Office of Vietnam (GSO). (2008). Vietnam's statistical yearbook. General Statistics Office, Vietnam. (In Vietnamese). Retrieved December, 20, 2012 from http://www.gso.gov.vn/default_en.aspx?tabid=515\&idmid=5\&ItemID=9233

General Statistic Office of Vietnam (GSO). (2009). Khanh Hoa's statistic yearbook. Khanh Hoa, Vietnam: General Statistic Office. (In Vietnamese).

Larkin, S. (2011). Practical considerations in using bioeconomic modelling for rebuilding fisheries. $O E C D$ Food, Agriculture and Fisheries Papers, No. 38. OECD. http://dx.doi.org/10.1787/5kgk9qclw7mv-en

Nøstbakken, L., \& Bjørndal, T. (2003). Supply function for north sea herring. Marine Resource Economics, 18, 345-361.

Organisation for Economic Co-operation and Development (OECD). (2012). Rebuilding Fisheries: The Way Forward, OECD Publishing. http://dx.doi.org/10.1787/9789264176935-en

Phan, L. T., \& Luc, N. V. (1991). Biological characteristic of anchovy (Stolephorus) genus in the coastal Vietnam. In Proceedings of Marine Fisheries Research (Vol. III, pp. 51-58). Hai Phong, Vietnam: Research Institute of Marine Fisheries.

Phung, N. H. (1978). Anchoviella Larva in Quang Ninh-Hai Phong coastal area. In Proceedings of Marine Fisheries Research (Vol. I, pp. 175-179). Hai Phong, Vietnam: Research Institute of Marine Fisheries.

Pomeroy, R. S. (2010). Addressing overcapacity of the small-scale marine fisheries in Vietnam. Retrieved from http://www.oecd.org/tad/fisheries/43018729.pdf

Pomeroy, R. S. (2012). Managing overcapacity in small-scale fisheries in southeast Asia. Marine Policy, 36(2), 520-527. http://dx.doi.org/10.1016/j.marpol.2011.10.002

Ricker, R. E. (1954). Stock and recruitment. Journal of the Fisheries Research Board of Canada, 11, $559-623$. http://dx.doi.org/10.1139/f54-039

Research Institute for Marine Fisheries (RIMF). (2001). Final summary report, assessment of the marine resources in Viet Nam in the period of 1996-2000. Hai Phong, Vietnam.

Research Institute for Marine Fisheries (RIMF). (2006). Final summary report, assessment of the marine resources in Viet Nam in the period of 2001-2005. Hai Phong, Vietnam.

Schaefer, M. B. (1954). Some aspects of the dynamics of population important to the management of the commercial marine fisheries. Inter-American Tropical Tuna Commission Bulettin, 1(2), 25-56.

State Bank of Vietnam. (2012). On the base inter-bank average exchange rate. Retrieved December 20, 2012 from http://www.sbv.gov.vn 
Stobutzki, I. C., Silvestre, G. T., \& Garces, L. R. (2006). Key issues in coastal fisheries in south and southeast Asia, outcomes of a regional initiative. Fisheries Research, 78, 109-118. http://dx.doi.org/10.1016/j.fishres.2006.02.002

Thi, D. V., Bat, N. K., Nguyen, D. V., Anh, P. V., Nghia, N. V., Ha, V. V, .. Thanh, N. D. (2007). Anchovy stock assessment in southwest Vietnam, and the solutions for sustainable management. Hai Phong, Vietnam: Research Institute of Marine Fisheries.

Thuoc, P. (2001). Scientific basis for sustainable management of coastal fisheries resources in Vietnam. In Proceedings of Marine Fisheries Research (Vol. II, pp. 279-300). Hai Phong, Vietnam: Research Institute of Marine Fisheries.

Thuy, T. T. P., Flaaten, O., \& Kim Anh, T. N. (2013). Remuneration systems and economic performance: Theory and Vietnamese small-scale purse seine. Marine Resource Economics (in press). http://dx.doi.org/10.5950/0738-1360-28.1.19

World Bank. 2012. On the data on inflation, consumer prices. Retrieved December, 20, 2012 from http://data.worldbank.org

Zwieten van, P. A. M, van Densen, W. L. T., \& Thi, D. V. (2002). Improving the usage of fisheries statistics in Vietnam for production planning, fisheries management and nature conservation. Marine Policy, 26, 13-34. http://dx.doi.org/10.1016/S0308-597X(01)00036-7

\section{Notes}

Note 1. In 2011, 20828 VND equaled 1.0 USD (State Bank of Vietnam, 2012). The consumer price indices are reported by World Bank (2012).

Note 2. The species are reported to occur in Vietnamese water (Thi et al., 2007).

Note 3. Several small vessels were sold to other provinces or stopped fishing because of consecutive losses for years, according to personal communication in 2012 by Mr. Phan Van Tan, Director of the Fisheries Department of Cam Ranh city. 


\section{Appendix A}

The MSY produced price and corresponding harvest are derived by taking the derivatives of the harvest with respect to the price and assigning it into zero:

\section{Model 1}

$d H / d p=a e^{-b\left(p_{M S Y}-p_{o}\right)}\left(1-b p_{M S Y}-b p_{o}\right)=>p_{M S Y}=1 / b+p_{o}$ and $H_{M S Y}=a / b e$

Model 2 - Based on Gordon-Schaefer model

$d H / d p=r K p_{o} / p_{M S Y}^{2}\left(-1+2 p_{o} / p_{M S Y}\right)=0 \Rightarrow p_{M S Y}=2 p_{o} \quad$ and $\quad H_{M S Y}=r K / 4$

Model 3 - Based on Ricker model

$d H / d p=0 \leftrightarrow e^{r\left(1-p_{o} / p_{M S Y}\right)}\left(1-r p_{o} / p_{M S Y}\right)=1 \Rightarrow H_{M S Y}=K p_{o} / p_{M S Y}\left(1 /\left(1-r p_{o} / p_{M S Y}\right)-1\right)$

To determine $p_{M S Y}$, we apply the Newton's method, also known as the Newton-Raphson method. It is implemented as follows:

Given a function $f$ defined over $X_{t}$, and its derivative $f^{\prime}$, approximation of $X_{t+1}$ will be:

$$
X_{t+1}=X_{t}-f\left(X_{t}\right) / f^{\prime}\left(X_{t}\right)
$$

A challenge when applying non-linear regression for this model is to find out good initial values for $\alpha, \beta, \gamma$. Bad initial values might end up with under- or overestimated results. In order to get initial values for $\alpha, \beta, \gamma$, we need to know $p_{o}, r, K$. We determine minimum price, $p_{o}$, by letting it equal to the minimum affordable price that the owner of the most cost efficient vessel is willing to sell. This means that it is exactly $p_{o}$ in model $1\left(p_{0}=2.78\right)$. Regarding the intrinsic growth rate, $r$, we borrow the lowest one among the growth rates that Thi et al. (2007) reported for different anchovy species $(r=0.53)$. With respect to the value of carrying capacity, this is the most difficult one since we have no explicit information. We therefore pick up the value of the current biomass for anchovy that Thi et al. (2007) reported $(B \approx 120000)$. This figure is evaluated slightly higher than the MSY level for anchovy purse seine fisheries in the study. Hence, we can extrapolate the initial carrying capacity $(K=240000)$.

Model 4 - Based on Gompertz-Fox model

$$
\frac{d H}{d p}=r K p_{o} / p_{M S Y}{ }^{2}\left[\ln p_{o} / p_{M S Y}+1\right]=0=>p_{M S Y}=e p_{o} \text { and } H_{M S Y}=r K / e
$$




\section{Appendix B}

\section{ANNUAL SURVEY ON PURSE SEINE FISHING VESSELS IN NHA TRANG CITY, VIETNAM}

\section{General information:}

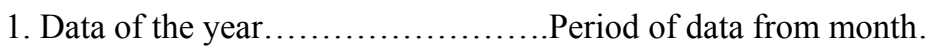
to. month

2. Time of survey:

Date. month. ..year...

3. Main fishery Other

4. Name of interviewer

5. Phone number of interviewer

\section{Vessel characteristics}

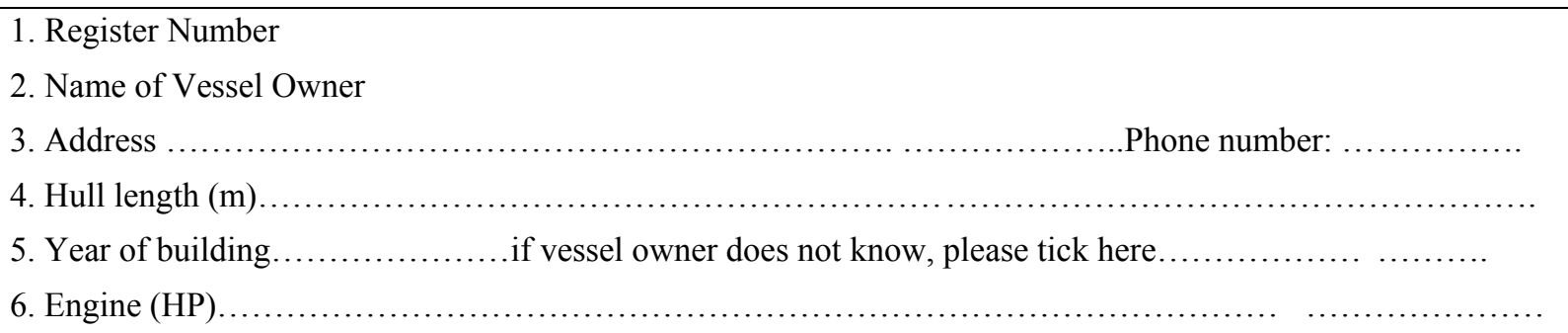

\section{Information about labor}

\begin{tabular}{|c|c|}
\hline Skipper & Crew (including skipper) \\
\hline $\begin{array}{l}\text { 1. Skipper information } \\
\text { a. Does skipper have license? yes.............no } \\
\text { b. Skipper educational level. } \\
\text { c. Skipper age } \\
\text { d. Skipper experience } \\
\text { e. Skipper vocational training time } \\
\text { f. Does skipper come from traditional fishing } \\
\text { household? }\end{array}$ & $\begin{array}{l}\text { 2. Average annual crew size (persons) } \\
\text { 3. Income/person (1000 VND) } \\
\text { a. Average income/trip in the main season } \\
\text { b. Average income/trip in other season }\end{array}$ \\
\hline
\end{tabular}

IV. Information about harvested quantity and price, operating time

\begin{tabular}{|l|l|l|}
\hline & Main season & Other season \\
\hline 1. Number of trips & & \\
\hline 2. Quantity of harvested species per trip & & \\
b. Main species $1(\mathrm{~kg})$ & & \\
c. Main species $2(\mathrm{~kg})$ & & \\
d. Main species $4(\mathrm{~kg})$ & & \\
f. Others $(\mathrm{kg})$ & & \\
\hline 3. Average annual price & & \\
a. Main species 1 & & \\
b. Main species 2 & & \\
c. Main species 3 & & \\
d. Main species 4 & & \\
f. Others & & \\
\hline
\end{tabular}




\section{Capital Items}

\begin{tabular}{|c|c|c|c|c|c|c|c|}
\hline & \multirow{2}{*}{$\begin{array}{l}\text { Year of } \\
\text { purchase }\end{array}$} & \multirow{2}{*}{$\begin{array}{l}\text { Physical } \\
\text { units }\end{array}$} & \multicolumn{3}{|c|}{ Monetary units } & \multirow{2}{*}{$\begin{array}{l}\text { Condition } \\
\text { at time of } \\
\text { purchase } \\
\text { (old or } \\
\text { new) }\end{array}$} & \multirow{2}{*}{$\begin{array}{l}\text { Estimated } \\
\text { lifespan }\end{array}$} \\
\hline & & & $\begin{array}{l}\text { Purchase } \\
\text { price } \\
(1000 \\
\text { VND or } \\
\text { gold) }\end{array}$ & $\begin{array}{l}\text { Current } \\
\text { estimated } \\
\text { price }\end{array}$ & $\begin{array}{l}\text { Estimated } \\
\text { price if } \\
\text { buy a } \\
\text { new one } \\
\text { with the } \\
\text { same size } \\
\text { and } \\
\text { technical } \\
\text { standard }\end{array}$ & & \\
\hline \multicolumn{8}{|l|}{ 1. Hull } \\
\hline \multicolumn{8}{|l|}{ 2. Engine } \\
\hline \multicolumn{8}{|l|}{$\begin{array}{l}\text { 3. Auxiliary engine } \\
\text { (generator) }\end{array}$} \\
\hline 4. Mechanic equipment & & - & - & & & - & - \\
\hline \multicolumn{8}{|l|}{ a. Winch } \\
\hline \multicolumn{8}{|l|}{$\begin{array}{l}\text { b. Normal lighting } \\
\text { system (batteries and } \\
\text { lamps) }\end{array}$} \\
\hline \multicolumn{8}{|l|}{$\begin{array}{l}\text { c. Special lighting } \\
\text { system for fishing }\end{array}$} \\
\hline \multicolumn{8}{|l|}{$\begin{array}{l}\text { d. Other mechanic } \\
\text { equipment }\end{array}$} \\
\hline 4. Electronic equipment & & - & - & & & - & - \\
\hline \multicolumn{8}{|l|}{ a. GPS } \\
\hline \multicolumn{8}{|l|}{ b. Compass } \\
\hline \multicolumn{8}{|l|}{ c. Short-range radio } \\
\hline \multicolumn{8}{|l|}{ d. Long-range radio } \\
\hline 5. Gear & & - & - & & & - & - \\
\hline \multicolumn{8}{|l|}{ a. Fishing net } \\
\hline \multicolumn{8}{|l|}{ b. Long-lining } \\
\hline \multicolumn{8}{|l|}{ c. Hooks } \\
\hline \multicolumn{8}{|l|}{ d. Subgear } \\
\hline 6. Freezing equipment & & & & & & & \\
\hline
\end{tabular}

\section{Annual Repair and Maintenance}

\begin{tabular}{|l|l|}
\hline & Costs (1000VND) \\
\hline 1. Hull & \\
\hline 2. Engine & \\
\hline 3. Fishing gear & \\
\hline 4. Others & \\
\hline 5. Total & \\
\hline
\end{tabular}


VII. Improvement/Investment

\begin{tabular}{|l|l|l|l|}
\hline & $\begin{array}{l}\text { Last year of } \\
\text { improvement }\end{array}$ & Costs (1000 VND) & Duration (years) \\
\hline 1. Hull & & & \\
\hline 2. Engine & & & \\
\hline 3. Gear & & & \\
\hline 4. Others & & & \\
\hline 5. Total & & & \\
\hline
\end{tabular}

VIII. Insurance and Tax

\begin{tabular}{|l|l|}
\hline & Costs (1000 VND) \\
\hline 1. Insurance & \\
\hline 2. Resource tax & \\
\hline 3. Business tax & \\
\hline 4. Other & \\
\hline
\end{tabular}

\section{Loan}

\begin{tabular}{|l|l|l|l|}
\hline & $\begin{array}{l}\text { Debt at the end } \\
\text { of year (1000 } \\
\text { VND) }\end{array}$ & $\begin{array}{l}\text { Interest payment } \\
\text { VND) }\end{array}$ & \\
\hline Bank & & & per year (1000 per month \\
\hline 2. Private loan & & & \\
\hline $\begin{array}{l}\text { 3. Government project } \\
\text { loan }\end{array}$ & & & \\
\hline
\end{tabular}

\section{$X$. Average operating costs/trip}

\begin{tabular}{|l|l|l|l|l|}
\hline \multirow{2}{*}{} & \multicolumn{2}{|l|}{ Main season } & \multicolumn{2}{l|}{ Other season } \\
\cline { 2 - 5 } & Quantity & $\begin{array}{l}\text { Value (1000 } \\
\text { VND) }\end{array}$ & Quantity & Value (1000 VND) \\
\hline 1. Fuel & & & & \\
\hline a. Oil (diesel) (liter) & & & & \\
\hline b. Lubricant (unit) & & & & \\
\hline 2. Ice & & & & \\
\hline 3. Bait & & & & \\
\hline 4. Food and & & & & \\
\hline $\begin{array}{l}\text { 5. Minor repair } \\
\text { maintenance }\end{array}$ & & & & \\
\hline 6. Other costs & & & & \\
\hline Total (from 1-6) & & & & \\
\hline
\end{tabular}

